for central government. Nevertheless anything is possible because article 150 says that the central government may transfer or delegate to autonomous communities matters attributed to it.

The reason why the organisation of research is mentioned in the Constitution comes from the present unequal distribution of research centres in Spain. The question is left open because some people think that if control over research is given to autonomous governments research would be more balanced and related to the needs of different areas; others fear that it could be more difficult for a smaller community to build an appropriate system of financing research and that coordination may not be easy.

Parliament will have to make a decision on these issues within the next few months. From a practical point of view it is very important that decisions are made quickly as the present provisional situation in science makes work very difficult. For instance

\title{
Sweden's new government wrestles with nuclear power
}

NUCLEAR power has finally proved to be the undoing of Sweden's first nonsocialist coalition government in 44 years. Former Prime Minister Torbjörn Fälldin handed his resignation to the Speaker on 5 October.

The government fell because some members of Fälldin's Centre Party opposed the coalition's decision on the loading of two reactors: Ringhals 3 and Forsmark 1. Under the Stipulation Law, the reactor owners could be given permission to load only after they had secured an acceptable reprocessing contract. They also had to show how and where the highly-radioaotive waste resulting from reprocessing could be finally stored. Judging the application by these criteria, the government found "that the preconditions for consent are deficient in one respect. The application cannot therefore be approved".

The government went on to say that in order for the application to meet the conditions laid down for secure final storage, there should be test drilling to "show the existence of a sufficiently large rock formation of appropriate depth" with the qualities already prescribed by the nuclear industry's Nuclear Fuel Safety (KBS) project*. If the applicants found rock they considered suitable and applied again, the government would ask the Nuclear Power Inspectorate to judge the application. If the Inspectorate approved it, the government would give permission for the reactors to be loaded.

This agreement was immediately interpreted by the Press as a 'soft yes' to the loading, as it was assumed that the test drilling was a mere formality which would quickly produce the required rock. The Centre Party was criticised for yet another capitulation: although anti-nuclear, it had made several compromises on the issue during the government's term. How much influence these attacks had is uncertain, but, at the insistence of former Energy Minister Olof Johansson and other members of the Centre Party, Fälldin demanded that his coalition partners should agree to a referendum on the issue. They refused, and the government fell.

After much speculation, a minority Liberal party government was sworn in on 18 October. The new Energy Minister, Carl Tham, favours nuclear energy, but his statements since becoming Minister have been cautious.

Tham has said that the investments already made in nuclear reactors should not be wasted, and that those already in operation or being constructed should be used if security demands can be met. This would mean drawing the nuclear line at eleven reactors. He also wants to tighten up security on all energy forms. The new government will, he says, follow the old one's agreement on the Ringhals 3 and Forsmark 1 reactors.

Since the government's fall, debate has raged over the extra drilling requirements. Will they prove to be a simple formality, or was this a subtle way of delaying the two reactors perhaps for years? Engineer Lars Bertil Nilsson, chief of the KBS project, is confident that suitable rock will be found quickly. "There are certainly many places in Sweden where the rock is suitable", he says. "According to the government's statement, we simply have to find one of them. We don't need to choose any particular place now for final storage: that's a longterm business and will need to take a lot of other things into account besides the rock itself: buildings, transport, public opinion, etc. All we have to do now is to show that suitable rock exists. It is our judgement that we need only drill four new holes at Finnsjön, near Forsmark, and three new ones at Karlshamn. The drilling has just begun and will be finished by the end of the year. Then we'll put our report together and make a new application to the government in 1979."

His optimism is not shared by various researchers and some of the geologists actually doing the drilling. They have claimed that reliable results cannot be expected before two to ten years. one of the main sources of research funds (FNDICT) may disappear next year and laboratories have not yet received the credits corresponding to applications made in 1977.

What remains to be seen is if political decisions will be taken soon enough to prevent the closing of certain laboratories and if the problems are treated with sufficient imagination to achieve an adequate structure for research.

Pedro Puigdoménech

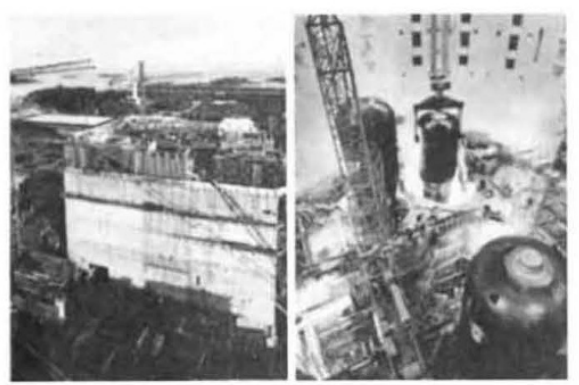

Forsmark 1 and Ringhals 3 under construction.

Meanwhile, the Nuclear Power Inspectorate is preparing itself for the new application. According to Dr Thomas Johansson, Vice-Chairman of the Inspectorate's Board, an expert panel of geologists is being set up to review the application. Before it is presented, however, the board is asking the panel to discuss guidelines for its evaluation. The panel should list the qualities that the nuclear power industry has said suitable rock should have; discuss possible measuring techniques that could be used to claim that the rock actually has the required characteristics; and decide what constitutes "showing" that the rock is suitable. "None of the geologists on the panel is involved in the drilling", says Dr Johansson. "The intention is to have a completely independent review."

What, then, of the future? "I am rather pessimistic", says anti-nuclear activist Björn Gillberg. "The Centre Party committed suicide when it passed the Stipulation Law. Whether or not we want nuclear energy should be decided on very broad grounds: social, political, psychological, environmental, international. To reduce it to the technical handling of waste, as the Law does, simply turned out to be a trap. The Centre Party didn't realise it had set a trap for itself until it was too late. They're nice guys, but they're naive. I can see the [pro-nuclear] Social Democrats winning next year's elections." Wendy Barnaby

*The first KBS report, against which the Ringhals 3 application was judged, is called "Handling of Spent Nuclear Fuel and Final Storage of Vitrified High Level Reprocessing Waste". It is available from KBS, Brahegatan, S-102 40 Stockholm. 